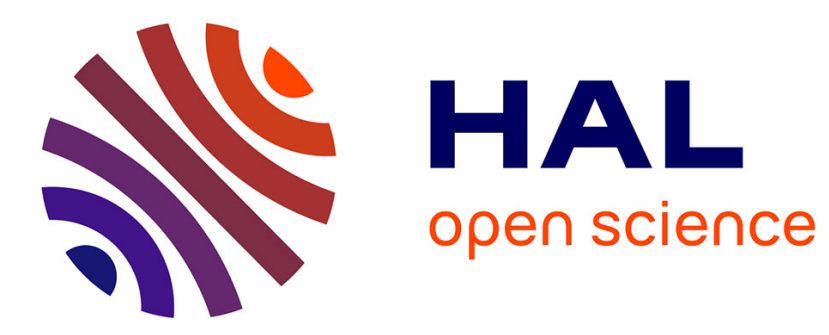

\title{
Currency Misalignments and Growth: A New Look using Nonlinear Panel Data Methods
}

Sophie Bereau, Antonia Lopez-Villavicencio, Valerie Mignon

\section{To cite this version:}

Sophie Bereau, Antonia Lopez-Villavicencio, Valerie Mignon. Currency Misalignments and Growth: A New Look using Nonlinear Panel Data Methods. Applied Economics, 2012, 44, pp.3503-3511. 10.1080/00036846.2011.577022 . hal-00709558

\section{HAL Id: hal-00709558 https://hal.science/hal-00709558}

Submitted on 19 Jun 2012

HAL is a multi-disciplinary open access archive for the deposit and dissemination of scientific research documents, whether they are published or not. The documents may come from teaching and research institutions in France or abroad, or from public or private research centers.
L'archive ouverte pluridisciplinaire HAL, est destinée au dépôt et à la diffusion de documents scientifiques de niveau recherche, publiés ou non, émanant des établissements d'enseignement et de recherche français ou étrangers, des laboratoires publics ou privés. 


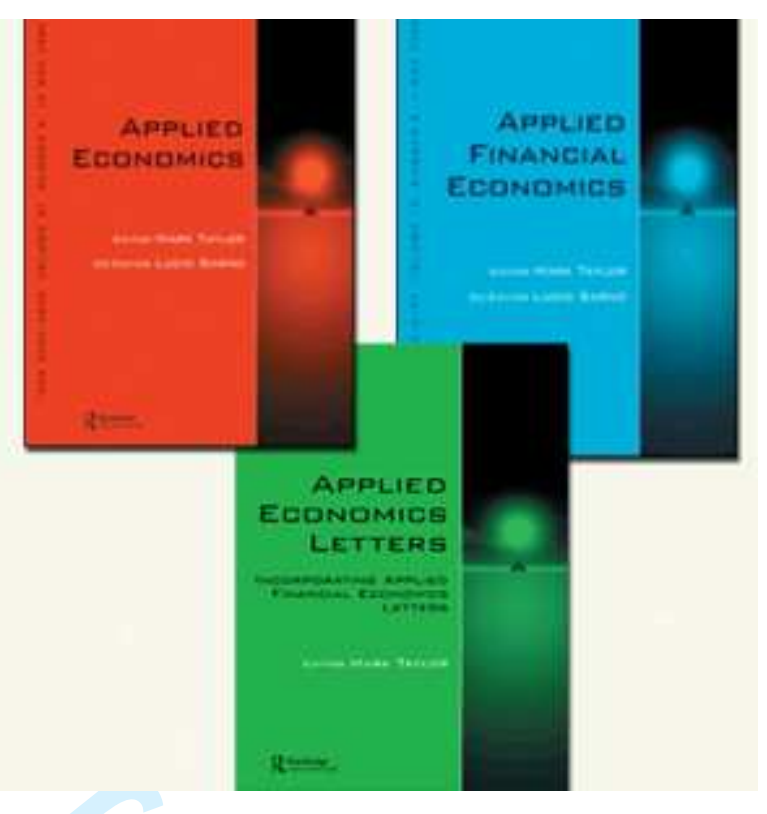

\section{Currency Misalignments and Growth: A New Look using Nonlinear Panel Data Methods}

\begin{tabular}{|c|c|}
\hline Journal: & Applied Economics \\
\hline Manuscript ID: & APE-2009-0647.R1 \\
\hline Journal Selection: & Applied Economics \\
\hline $\begin{array}{r}\text { Date Submitted by the } \\
\text { Author: }\end{array}$ & 06-Sep-2010 \\
\hline Complete List of Authors: & $\begin{array}{l}\text { Bereau, Sophie; University of Paris Ouest } \\
\text { Lopez-Villavicencio, Antonia; University of Paris } 13 \\
\text { MIGNON, Valerie; University of Paris } 10\end{array}$ \\
\hline JEL Code: & $\begin{array}{l}\text { F31 - Foreign Exchange < F3 - International Finance }<\text { F - } \\
\text { International Economics, O47 - Measurement of Economic } \\
\text { Growth|Aggregate Productivity }<04-\text { Economic Growth and } \\
\text { Aggregate Productivity < O - Economic Development, Technological } \\
\text { Change, and Growth, C23 - Models with Panel Data < C2 - } \\
\text { Econometric Methods: Single Equation Models < C - Mathematical } \\
\text { and Quantitative Methods }\end{array}$ \\
\hline Keywords: & growth, exchange rate misalignments, nonlinearity, PSTR models \\
\hline
\end{tabular}




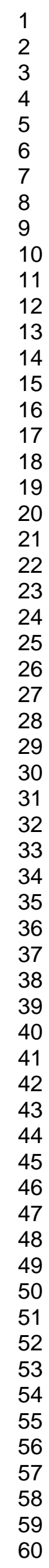

\section{SCHOLARONE ${ }^{m}$ \\ Manuscripts}

7

25

26

27
28

29

30

32

33

34

35

36

37

38

40

41

42

44

45

46

47

48

49

51

52

54

55

57

58

59

60 


\title{
Currency Misalignments and Growth: A New Look using Nonlinear Panel Data Methods*
}

\author{
Sophie Béreau $^{\dagger} \quad$ Antonia López Villavicencio ${ }^{\ddagger} \quad$ Valérie Mignon $^{\S}$
}

September 6, 2010

\begin{abstract}
The aim of this paper is to investigate the link between currency misalignments and economic growth. Relying on panel cointegration techniques, we calculate real exchange rate (RER) misalignments as deviations of actual RERs from their equilibrium values for a set of advanced and emerging economies. Estimating panel smooth transition regression models, we show that RER misalignments have a differentiated impact on economic growth depending on their sign: whereas overvaluations negatively affect economic growth, real exchange rate undervaluations significantly enhance it. This result indicates that undervaluations may drive the exchange rate to a level that encourages exports and promotes growth.
\end{abstract}

JEL Classification: F31, O47, C23

Keywords: Growth, exchange rate misalignments, nonlinearity, PSTR models.

\footnotetext{
${ }^{*}$ Corresponding author: Valérie Mignon, EconomiX-CNRS, University of Paris Ouest, 200 avenue de la République, 92001 Nanterre Cedex, France. E-mail: valerie.mignon@u-paris10.fr. Phone: +33 (0)1 4097 58 60. Fax: +33 (0)1 409777 84. We thank Agnès Bénassy-Quéré, Jacques Melitz and an anonymous referee for very useful and stimulating remarks and suggestions.

${ }^{\dagger}$ EconomiX-CNRS, University of Paris Ouest, France. E-mail: sophie.bereau@u-paris10.fr

${ }^{\ddagger}$ CEPN-CNRS, University of Paris 13, France. E-mail: lopezvillavicencio@univ-paris13.fr

${ }^{\S}$ EconomiX-CNRS, University of Paris Ouest and CEPII, Paris, France. E-mail: valerie.mignon@ u-paris10.fr
} 


\section{Introduction}

There has recently been a revival of interest in equilibrium exchange rates' assessment due to the current context of global imbalances. Indeed, since the end of the 1990s, the accelerating financial integration process accompanied with the preeminence of capital movements over trade in goods between countries, has engendered a growing disconnection between exchange rate fluctuations and the real economic activity. Within this context, and in order to better understand the sources of exchange rate movements, it may be useful for monetary authorities to rely on specific tools allowing assessment of long-run values for the real exchange rates that would be consistent with the realization of a long-run stable macroeconomic equilibrium. To this end, various approaches aiming at defining "equilibrium exchange rate" concepts have been developed, among which the "Behavioral Equilibrium Exchange Rate" (BEER) introduced by Clark and MacDonald (1998). ${ }^{1}$

If numerous contributions have explored the links between exchange rate volatility on different exchange rate regimes and growth, ${ }^{2}$ the influence of long-run exchange rate misalignments ${ }^{3}$ on real economic activity remains an open question. Yet, it seems particularly interesting to focus on the impact of currency misalignments on growth since persistent real exchange rate gaps are likely to affect the economic performance of countries. Indeed, persistent misalignments may induce distortions in relative prices of traded over non-traded goods that may be misinterpreted by economic agents and, as a consequence, may generate instability (see e.g. Edwards (1989)).

In addition, the effects may be differentiated in case of an over- or under-valuation of currencies. Indeed, it has been argued that, when the currency is undervalued, competitiveness is reinforced, stimulating domestic production, investment and exports, and reducing imports (see, among others, Dooley, Folkerts-Landau and Garber (2005)). The current account is then improved, so are GDP and employment. Conversely, currency overvaluations are rather interpreted as proofs of incoherent macroeconomic policy decisions (Razin and Collins (1997)), point to an increasing probability of balance of payment crises and of possible currency crashes (Krugman (1979)), and contribute to deteriorate growth. Therefore, the growth effects of real exchange rate misalignments may vary with the level and/or the sign of the current misalignment.

From an empirical viewpoint, the majority of studies dealing with the misalignment-growth nexus find a negative link between currency misalignments and economic growth in develop-

\footnotetext{
${ }^{1}$ Various other alternative approaches of equilibrium exchange rates have also been proposed in the literature; for an extensive survey, see Driver and Westaway (2004).

${ }^{2}$ See the seminal paper of Baxter and Stockman (1989), and the references given in Béreau, López Villavicencio and Mignon (2009).

${ }^{3}$ The misalignment is defined as the deviation of the observed real exchange rate from its equilibrium level.
} 
ing countries. ${ }^{4}$ This result may however be challenged by considering the sign and the size of the misalignment. Indeed, in their noticeable contribution, Aguirre and Calderón (2005) estimate a standard growth equation on a large panel of emerging economies and show that misalignments hinder growth but in a non-linear way: growth declines are larger, the larger the size of the misalignments. Although large undervaluations hurt growth, small to moderate undervaluations can enhance it. Studying Latin American countries, Frenkel (2004) finds that the overvaluation of their currencies constitutes one of the main explanation of crises and stagnation affecting these countries during the 1990s and 2000s. The importance of accounting for the sign of the misalignment is also highlighted by Polterovich and Popov (2004) showing the existence of a positive relationship between economic growth and undervalued currencies.

The aim of this paper is to investigate the relationship between real exchange rate misalignments and economic growth, by paying a special attention to the potential differentiated effects previously described. Our contribution is threefold. First, while most of the previous studies consider developing countries, we rely on a wider sample of countries, including both developed and developing economies. Accounting for a large sample of countries is of particular importance in the current context of global imbalances, that calls for a consistent set of equilibrium exchange rates. Second, we conduct a detailed analysis to derive robust measures of currency misalignments by relying on the BEER methodology. In this sense, we go further than most of the existing literature investigating the link between currencies and economic growth based on PPP measures of exchange rates. Third, we specifically account for the sign (and the size) of the misalignment by estimating a panel nonlinear model. More specifically we rely on the estimation of a Panel Smooth Transition Regression (PSTR) model, allowing for a differentiated impact of currencies' overvaluations and undervaluations on economic growth.

The remainder of the paper is organized as follows. Section 2 outlines our methodology relating to (i) the estimation of currency misalignments, (ii) the choice of the growth determinants, and (iii) the PSTR models aiming at accounting for potential differentiated impacts of exchange rate misalignments on economic growth. Section 3 briefly describes the data and Section 4 presents the results. Finally, Section 5 provides some concluding remarks.

\section{Methodology}

\subsection{Estimation of currency misalignments}

To obtain currency misalignments, we rely on the BEER approach that consists in estimating a long-term relationship between the real effective exchange rate and its fundamentals. The equilibrium exchange rate is thus allowed to change over time, reflecting changes in economic fundamentals and domestic policies.

\footnotetext{
${ }^{4}$ See Béreau et al. (2009) for a survey.
} 
More specifically, we estimate the following relationship: ${ }^{5}$

$$
q_{i, t}=\alpha_{i}+\beta_{1} n f a_{i, t}+\beta_{2} t_{o t} t_{i, t}+\beta_{3} \operatorname{prod}_{i, t}+\varepsilon_{i, t}
$$

where $i=1, \ldots, N$ denotes the country, and $t=1, \ldots, T$ the time. $q_{i, t}$ denotes the real effective exchange rate (in logarithms), $n f a_{i, t}$ is the net foreign asset position expressed as percentage of GDP, tot $_{i, t}$ is the logarithm of terms of trade, and $\operatorname{prod}_{i, t}$ stands for the relative productivity in the traded-goods sector (relative to the non-traded goods one) in logarithms. $\varepsilon_{i, t}$ is an error term and $\alpha_{i}$ accounts for country-fixed effects. The estimation of Equation (1) through efficient panel cointegration techniques (see below) gives the real equilibrium exchange rate values $\left(\hat{q}_{i t}\right)$ and the corresponding misalignments $\left(m_{i, t}=q_{i, t}-\hat{q}_{i, t}\right)$ for each considered country.

\subsection{Augmented growth equation}

To investigate the impact of currency misalignments on economic growth, we add the misalignment series to the right-hand side variables that are usually considered in growth equations. More specifically, not accounting for nonlinearities, we consider a model of the following form:

$$
\Delta y_{i, t}=\mu_{i}+\Omega X_{i, t}+\theta m_{i, t}+u_{i, t}
$$

where $y_{i, t}$ is the real GDP per capita, $X_{i, t}$ is a vector of contemporaneous and lagged values of growth determinants, $m_{i, t}$ denotes currency misalignments and $u_{i, t}$ is an error term. $\mu_{i}$ is a vector of individual fixed effects.

Despite the vast number of cross-country growth studies that followed the seminal papers of Barro (1991) and Mankiw, Romer and Weil (1992), there remains a broad number of possible specifications concerning the choice of the regressors. ${ }^{6}$ In the line of the neoclassical growth theory, we account for the initial position of the economy through the initial level of real GDP per capita to control for conditional convergence (see Barro and Sala-i Martin (1995) among others). Turning to other variables that may characterize the specificities of the various considered countries, we consider a measure of human capital given by the rate of gross secondary-school enrollment (see Barro (1991) and Mankiw et al. (1992) among others). Relying on some developments of the endogenous growth theory, we include the following determinants reflecting trade and macroeconomic stabilization policies, and institutions: (i) trade openness, (ii) fixed investment (in percentage of GDP), (iii) the inflation rate to account for price level stability and (iv) population growth. ${ }^{7}$ Finally, in addition to these usual de-

\footnotetext{
${ }^{5}$ See Bénassy-Quéré, Béreau and Mignon (2009) for a review of possible specifications, and detailed justifications of the retained fundamentals.

${ }^{6}$ See Sala-i Martin (1997) for a complete list.

${ }^{7}$ Note that we have also considered other usual growth determinants. Following Barro (1991) and Barro and Sala-i Martin (1995), we have introduced government consumption (in percentage of GDP) as an indicator
} 
terminants, we include currency misalignments in order to investigate the impact of exchange rate overvaluations and undervaluations on economic growth.

\subsection{Dealing with nonlinearities: the PSTR approach}

Let $\left\{z_{i, t}, s_{i, t}, x_{i, t} ; t=1, \ldots, T ; i=1, \ldots, N\right\}$ be a balanced panel with $z_{i, t}$ denoting the dependent variable, $s_{i, t}$ the threshold variable, and $x_{i, t}$ a vector of $k$ exogenous variables. The panel smooth transition regression (PSTR) model introduced by González, Teräsvirta and van Dijk (2005) can be written as follows:

$$
z_{i, t}=\mu_{i}+\beta_{0}^{\prime} x_{i, t}+\beta_{1}^{\prime} x_{i, t} g\left(s_{i, t} ; \gamma, c\right)+v_{i, t}
$$

where $\mu_{i}$ denotes the individual fixed effects, $g\left(s_{i, t} ; \gamma, c\right)$ is the transition function, normalized and bounded between 0 and $1, \gamma$ the speed of transition from one regime to the other and $c$ the threshold parameter. The threshold variable $s_{i, t}$ may be an exogenous variable or a combination of the lagged endogenous one.

In this model, the observations in the panel are divided into two regimes ${ }^{8}$ depending on whether the threshold variable is lower or larger than the threshold $c$. The error term $v_{i, t}$ is independent and identically distributed. The change from one regime to another is smooth and gradual, and is described by the following logistic transition function:

$$
g\left(s_{i, t} ; \gamma, c\right)=\left[1+\exp \left(-\gamma \prod_{j=1}^{m}\left(s_{i, t}-c_{j}\right)\right)\right]^{-1}
$$

with $\gamma>0$ and $c_{1} \leq c_{2} \leq \ldots \leq c_{m}$. González et al. (2005) mention that from an empirical point of view, it is sufficient to consider only the cases of $m=1$ (logistic PSTR) or $m=2$ (logistic quadratic PSTR) to capture the nonlinearities due to regime switching. The PSTR model is estimated following the three step strategy suggested by González et al. (2005).

On the whole, putting together Equations (2) and (3), our considered model of growth is given by:

$$
\begin{aligned}
\Delta y_{i, t}= & \mu_{i}+\underbrace{\Omega_{1} X_{i, t}+\theta_{1} m_{i, t}}_{\text {Regime } 1}+ \\
& {[\underbrace{\Omega_{2} X_{i, t}+\theta_{2} m_{i, t}}_{\text {Regime } 2_{-1}}] g\left(s_{i, t} ; \gamma, c\right)+u_{i, t} }
\end{aligned}
$$

of fiscal policy. The inclusion of this variable leading to very similar results to those reported here, they have been dropped to save space. It should be noticed that we do not consider terms of trade, which allows to account for cross-country differences in the external environment, since this determinant is already included in our misalignment variable. As a robustness check, we have however dropped terms of trade from the cointegrating relationship and included them in the growth equation, but this variable was not significant. All the corresponding estimation results are available upon request to the authors.

${ }^{8}$ Of course, it is possible to extend the PSTR model to more than two regimes. 
Depending on the realization of $s_{i, t}$, the link between $\Delta y_{i, t}$ and its determinants will be specified by a continuum of parameters, namely $\Omega_{1}$ and $\theta_{1}$ in Regime 1 (when $g()=$.0 ), and $\Omega_{1}+\Omega_{2}$ and $\theta_{1}+\theta_{2}$ in Regime 2 (Regime $1+$ Regime $2_{-1}$ ) when $g()=$.1 . Our main threshold variable of interest will be the misalignment $m_{i, t}$ or its lagged values. If two distinct growth regimes are associated with the misalignment as threshold variable, this would mean that exchange rate over- and under-valuations have a different impact on economic growth, especially if the threshold value is close to zero. In other words, this model allows us to investigate if nonlinearity in economic growth could be associated with changes in the magnitude and sign of the misalignment.

\section{Data}

To estimate our real misalignments and growth equations we use annual data over the 19802007 period for the following countries: Argentina, Australia, Brazil, Canada, Chile, China, Colombia, Costa Rica, Denmark, Egypt, United Kingdom, Hong-Kong, Indonesia, India, Israel, Japan, Korea, Mexico, Malaysia, Norway, New Zealand, Peru, Philippines, Singapore, Sweden, Switzerland, Thailand, Turkey, Uruguay, United States, Venezuela and the Euro area. Using such an extensive panel of both industrialized and emerging economies is a critical point to properly assess the impact of currency misalignments on growth. Indeed, if prior studies have focused either on developing countries or on developed ones, the need to derive consistent values of equilibrium exchange rates calls for a broader sample, including both types of economies.

Regarding the long-run BEER equation, from which we derive our measures of currency misalignments, the dependent variable is the real effective exchange rate $(q)$. It is CPI based, and expressed such that when it rises (resp. falls), it corresponds to an appreciation (resp. depreciation) of the considered currency in effective terms. The explanatory variables are the stock of net foreign assets $(n f a)$, the relative labor productivity of tradables to non tradables (prod), and the terms of trade (tot). All series are in logarithms, except $n f a$ which is expressed as share of GDP in percentage points. The detailed definitions and sources for all these variables are given in Appendix.

Turning now to our growth equation, the dependent variable is the growth rate of real GDP per capita and the explanatory variables are the initial value of the GDP per capita (in logarithms), real investment (as share of GDP), trade openness (sum of exports and imports, in proportion of GDP), population growth, gross-secondary school enrollment rate, and the inflation rate $^{9}$ (see Appendix).

\footnotetext{
${ }^{9}$ Denoting the inflation rate as $\pi_{i, t}$, we retain the following expression for inflation in the growth regression: $\log \left(1+\pi_{i, t}\right)$. This choice may be notably justified by the fact that the logarithmic transformation reduces the
} 


\section{Results}

\subsection{Estimating equilibrium exchange rates}

We start by applying panel unit root and cointegration tests. We consider various usual first generation unit root tests that rely on the assumption of cross-section independence among the panel members. ${ }^{10}$ Given that cross-sectional independence is a rather restrictive hypothesis in macroeconomic applications where co-movements of economies are often observed, we also apply the Bai and Ng (2004)'s second generation test that relaxes this assumption. In addition, given that our time sample covers a quite long period, we consider the Lee and Strazicich (2003)'s unit root test which is robust to the presence of structural breaks to avoid the well-known bias towards the non-stationarity hypothesis. All these tests conclude that series in Equation (1) are integrated of order 1. Turning now to the cointegration case, the use of the seven tests proposed by Pedroni $(1999,2004)$ as well as the Kao (1999)'s test conclude that exchange rate series and the three considered fundamentals are cointegrated. ${ }^{11}$

We then proceed to the estimation of the long-run relationship between the real exchange rate and the explanatory variables using the Pooled Mean Group (PMG) procedure proposed by Pesaran, Shin and Smith (1999). Compared to other techniques - such as the Fully ModifiedOLS or the Dynamic OLS procedures - the advantage of the PMG methodology is that, while slope homogeneity is imposed, short-run heterogeneity is allowed for each member of the panel. To check the validity of the PMG estimates, we test the slope homogeneity restriction using a Hausman test.

As reported in Table 1, results from the Hausman test indicate that the long-run parameters are homogeneous, justifying the choice of the PMG methodology. Regarding the estimation of the panel cointegration equation (Table 1), our findings appear consistent with the theory since the coefficients have the expected signs. Indeed, the real exchange rate appreciates $(q$ increases) in the long run if the net foreign asset position rises, the relative productivity increases, and the terms of trade improve.

\subsection{Estimating the nonlinear growth equation}

We start by testing the null hypothesis of linearity in model (5) using, as the relevant transition variable, our derived series of misalignments. ${ }^{12}$ In other words, we test if there exists some difference in the response of growth to positive and negative RER misalignments and if

asymmetry of the distribution of $\pi_{i, t}$-which is known to be highly skewed.

${ }^{10}$ See Hurlin and Mignon (2006) and Hurlin (2010) for a detailed presentation of panel unit root tests.

${ }^{11}$ Complete results from panel unit root and cointegration tests are available upon request to the authors.

${ }^{12}$ The same panel unit root tests as those mentioned in Subsection 4.1 have been applied to all variables included in Equation (5), which were found to be stationary. 
the transition from one regime to another depends on the size and the sign of the deviation of the RER from its equilibrium level. The linearity hypothesis being rejected at the $5 \%$ significance level for our panel of countries ${ }^{13}$ we therefore proceed to the estimation of the nonlinear growth relationship (Equation (5)).

In Table 2, we report the regression estimates of the PSTR model using a specification with a logistic transition function and two regimes. ${ }^{14}$ When the transition variable (i.e. the misalignment) is below the estimated threshold parameter $c$ in Equation (5), growth is defined by the estimated equation reported in Column labeled "Regime 1" in Table 2. On the contrary, if the transition variable exceeds the threshold parameter, growth is defined by the estimates reported in Column labeled "Regime 2" in the table. Our results show that our estimated threshold is equal to $2.4 \%$. This means that the first regime, characterized by $g()=$.0 , corresponds to undervaluations and small overvaluations, i.e. overvaluations less than $2.4 \%$. The second regime, corresponding to $g()=$.1 , is relating to overvaluations more than $2.4 \%$. There are, however, a continuum of points between these two extreme cases.

Let us first comment the results relating to the control variables. All the explanatory variables have the expected sign, whatever the sign and the size of the misalignment. Indeed, in both extreme regimes (i.e. when $g()=$.0 and $g()=$.1 ) the initial GDP per capita coefficient is negative, meaning that the conditional convergence hypothesis is evidenced. The coefficient of the inflation rate is significantly negative, indicating that price instability tends to hamper growth. The investment variable has also the right sign since there exists a positive relationship between capital accumulation and growth. Trade openness positively affects growth, a fact that is in line with both the neoclassical approach and the endogenous growth theory. Finally, as predicted by the Solow growth model, the population growth coefficient is negative.

Turning now to our main variable of interest, our results show that the misalignment has also the expected sign in the case of undervaluations. Indeed, in this first regime, the coefficient is equal to 0.052 meaning that, other things being equal, a depreciation of the real exchange rate of $10 \%$ contributes for an increase in GDP per capita growth of 0.52 percentage points. Undervaluations have thus a positive impact on economic growth, as expected. This result is consistent with those of Aguirre and Calderón (2005) and Dooley et al. (2005) and illustrates the fact that competitiveness is reinforced when the currencies are undervalued. More importantly, our findings put forward a differentiated effect of real exchange rate misalignments on growth, depending on whether they reflect over- or under-valuations of the considered currency: this impact varies between $0.52 \mathrm{pp}$. (Regime 1) and -0.38 pp. (Regime 2) on GDP

\footnotetext{
${ }^{13}$ Test results are available from the authors upon request.

${ }^{14}$ The rate of gross secondary-school enrollment has been excluded from the final estimation since this variable was not significant, confirming previous results by Romer (1989). Also, the choice between a logistic and a logistic quadratic model was based on information criteria and the lowest $p$-value in the linearity tests.
} 
per capita growth. In other words, while undervalued currencies stimulate growth, overvalued exchange rates hamper it. Put differently, the lower the overvaluations, the lower the negative impact on growth. This different impact of the exchange rate misalignment on growth clearly highlights the interest of our nonlinear specification and shows that exchange rate policy may play a key role in economic growth: appropriate exchange rate policies that limit currency overvaluation could be used to promote economic growth.

\subsection{Robustness checks}

\subsubsection{Nonlinear versus linear growth equation}

To put forward the interest of our nonlinear specification, we estimate a linear growth equation. For this purpose, we estimate the log-linear Equation (2) using the dynamic panel GMM estimator developed in Arellano and Bover (1995). Results reported in Table 3 show that (i) all the control variables have the expected signs, and (ii) the coefficient of the exchange rate misalignment is negative indicating that, whereas an overvalued currency tends to slow growth on average, undervaluations have a positive effect.

Such a linear specification is able to capture the differentiated effect of real exchange rate misalignments depending on the sign of the deviation, but is not able to capture other features, such as, for instance, size effects. Indeed, a linear specification has several drawbacks that are worth mentioning. First, by definition, in a linear equation, the growth-misalignment elasticity is constant. In our case, the estimated elasticity is equal to $-2.9 \%$, meaning that, if the currency is overvalued (resp. undervalued), an appreciation (resp. depreciation) of the real exchange rate of $10 \%$ would have a negative (resp. positive) effect on growth of about 0.29 pp., independently of the size of the misalignment. Second, the threshold value that divides positive from negative effects is, by construction, zero. Third, and related to the previous points, there is a symmetric - but opposite in sign - effect of under and over-valuations. For instance, an undervaluation (resp. overvaluation) of $10 \%$ has a positive (resp. negative) impact of approximately $0.30 \mathrm{pp}$. on GDP per capita growth. In this situation, a country which decides to depreciate its real exchange rate will "gain" exactly the same as a country facing an undervaluation of $50 \%$ of its currency. Finally the higher the misalignment, the more positive (in the case of undervaluations) or negative (in the case of overvaluations) the final effect on growth. However, there is no reason to think that this is necessarily the case, and such effects may come from the restrictive nature of the linear specification.

\subsubsection{Endogeneity issues in the PSTR model}

An important concern in growth regressions is the issue of endogeneity. Indeed, some of the explanatory variables, namely openness and fixed investment, could potentially be explained 
by unobserved common factors and, therefore, engender endogeneity problems that must be taken into account to avoid potential bias in the estimated parameters. Since trade openness and investment are not our main variables of interest here, we only proceed to robustness checks by instrumenting these two variables by their own lagged values. Results are reported in Table 4. Using two lags for each variable, our estimations show that the effects of the misalignment on economic growth are highly similar to those obtained in Table 2: a depreciation of the real exchange rate of $10 \%$ increases the GDP growth by about $0.50 \mathrm{pp}$., whereas a $10 \%$ appreciation reduces it by about $0.24 \mathrm{pp}$. Our findings that undervaluations tend to enhance growth, while overvaluations have a negative impact are thus robust to endogeneity issues.

\subsubsection{Misalignment measure}

As a final robustness check, we consider two alternative measures of real exchange rate misalignments: (i) instead of relying on fundamentals, we consider the deviation of the actual real exchange rate from its Hodrick-Prescott detrended value as in Goldfajn and Valdes (1999) among others, and (ii) following Chinn (1999), we rely on a PPP-based measure. In the first case, the filtered series represents the predicted equilibrium real exchange rate and captures the permanent changes in the series. In the second case, the equilibrium exchange rate is associated with an international version of the law of one price and is obtained by regressing the real exchange rate on a constant plus a time trend (when significant).

As shown in Table 5, while the impact of some variables on economic growth may slightly differ from the results reported in Table 2 - which is not surprising given that the misalignment series does not account for the fundamental determinants of the exchange rate - our findings are qualitatively similar. In particular, the effect of currency misalignment on growth is positive in case of undervaluations and negative for overvaluations, confirming our previous findings.

\section{Conclusion}

Various empirical studies have investigated the importance of variables such as the initial level of GDP, investment, human capital, trade openness and population growth, in explaining economic growth. However, not much has been done regarding the importance of real exchange rate misalignments as a potential determinant of growth. Our aim in this paper is to fill this gap by paying a special attention to the influence of exchange rate over- and under-valuations on the economic growth for a large set of countries, including both developing and advanced economies.

To this end, by estimating panel smooth transition regression models, we show that the im- 
pact of exchange rate misalignments on economic growth depends on the sign and the size of the misalignment. Indeed, we find that there exists a positive and significant relationship between growth and exchange rate misalignment when the currency is undervalued, whereas overvaluations negatively affect economic growth.

The previous result would imply that undervaluations, which could be attributed to competitive devaluations, may drive the exchange rate to a level that encourages exports and promotes growth. On the contrary, overvaluations discourage economic growth. These findings show that exchange rate policy may play a key role in economic growth and suggest that to boost performance, policymakers may undervalue their currencies.

\section{References}

Aguirre, A. and Calderón, C. (2005), Real Exchange Rate Misalignments and Economic Performance, Central Bank of Chile Working Papers 315, Central Bank of Chile.

Arellano, M. and Bover, O. (1995), 'Another look at the instrumental-variable estimation of error-component models', Journal of Econometrics 68, 29-51.

Bai, J. and Ng, S. (2004), 'A PANIC attack on unit roots and cointegration', Econometrica 72(4), 1127-1178.

Barro, R. (1991), 'Economic growth in a cross section of countries', The Quarterly Journal of Economics 106(2), 223-51.

Barro, R. and Sala-i Martin, X. (1995), Economic Growth, Mc Graw-Hill.

Baxter, M. and Stockman, A. (1989), 'Business cycles and the exchange rate regime', Journal of Monetary Economics 23(3), 377-400.

Bénassy-Quéré, A., Béreau, S. and Mignon, V. (2009), 'Robust Estimations of Equilibrium Exchange Rates: A Panel BEER Approach', Scottish Journal of Political Economy 56, 60833.

Béreau, S., López Villavicencio, A. and Mignon, V. (2009), Currency Misalignments and Growth: A New Look using Nonlinear Panel Data Methods (long version), Working Papers 2009-17, CEPII research center.

Chinn, M. (1999), 'Measuring misalignment: Purchasing power parity and East Asian currencies in the 1990s', IMF working paper (WP/99/120).

Clark, P. and MacDonald, R. (1998), Exchange Rates and Economic Fundamentals: A Methodological Comparison of BEERs and FEERs, IMF Working Papers 98/67, International Monetary Fund. 
Dooley, M. P., Folkerts-Landau, D. and Garber, P. M. (2005), Interest rates, exchange rates and international adjustment, NBER Working Papers 11771, National Bureau of Economic Research, Inc.

URL: http://ideas.repec.org/p/nbr/nberwo/11771.html

Driver, R. and Westaway, P. F. (2004), Concepts of equilibrium exchange rates, Working Paper 248, Bank of England.

Edwards, S. (1989), Real Exchange Rates, Devaluation and Adjustment: Exchange Rate Policy in Developing Countries, MIT Press edn.

Frenkel, R. (2004), Real exchange rate and employment in Argentina, Brazil, Chile and Mexico, Paper for the G-24, Washington DC.

Goldfajn, I. and Valdes, R. (1999), 'The aftermath of appreciations', Quarterly Journal of Economics 114, 229-262.

González, A., Teräsvirta, T. and van Dijk, D. (2005), Panel Smooth Transition Regression models, Research Paper 165, Quantitative Finance Research Centre, University of Technology, Sidney.

Hurlin, C. (2010), 'What would Nelson and Plosser find had they used panel unit root tests?', Applied Economics 42, 1515-1531.

Hurlin, C. and Mignon, V. (2006), Second generation panel unit root tests, Working papers, HAL.

IMF (2006), Methodology for CGER exchange rate assessments, Technical report, International Monetary Fund.

Kao, C. (1999), 'Spurious regression and residual-based tests for cointegration in panel data', Journal of Econometrics 190, 1-44.

Krugman, P. (1979), 'A model of balance-of-payments crises', Journal of Money, Credit and Banking 11, 311-25.

Lane, P. and Milesi-Ferretti, G. (2007), 'The external wealth of nations mark II: Revised and extended estimates of foreign assets and liabilities, 1970-2004', Journal of International Economics 73(2), 223-250.

Lee, J. and Strazicich, M. (2003), 'Minimum Lagrange multiplier unit root test with two structural breaks', The Review of Economics and Statistics 85, 1082-1089.

Mankiw, G., Romer, D. and Weil, D. (1992), 'A Contribution to the Empirics of Economic Growth', The Quarterly Journal of Economics 107(2), 407-37. 
Pedroni, P. (1999), 'Critical Values for Cointegration Tests in Heterogeneous Panels with Multiple Regressors', Oxford Bulletin of Economics and Statistics 61(s1), 653-670.

Pedroni, P. (2004), 'Panel Cointegration: Asymptotic and Finite Sample Properties of Pooled Time Series Tests With an Application to the PPP Hypothesis', Econometric Theory 20(03), 597-625.

Pesaran, M., Shin, Y. and Smith, R. P. (1999), 'Pooled Mean Group Estimation of Dynamic Heterogeneous Panels', Journal of the American Statistical Association 94(446), 621-634.

Polterovich, V. and Popov, V. (2004), Accumulation of foreign exchange reserves and long term growth, in S. Tabata and A. Iwashita, eds, 'Slavic Eurasia Integration into the World Economy', Slavic Research Center, Hokkaido University, Sapporo.

Razin, O. and Collins, S. M. (1997), Real Exchange Rate Misalignments and Growth, NBER Working Papers 6174, National Bureau of Economic Research, Inc.

Romer, P. M. (1989), Human capital and growth: theory and evidence, NBER Working Papers 3173, NBER.

Sala-i Martin, X. (1997), 'I Just Ran Two Million Regressions', American Economic Review $87(2), 178-83$. 
Table 1: PMG estimates for the equilibrium exchange rate equation

\begin{tabular}{l|cc}
\hline \hline Variable & Coeff. & $t$-stat \\
\hline Productivity (log) & 0.187 & 3.27 \\
NFA (\% GDP) & 0.177 & 5.02 \\
Terms of trade (log) & 0.15 & 4.716 \\
\hline \multicolumn{2}{c}{ Joint Hausman test: $4.30(0.13)$} \\
\hline \hline
\end{tabular}

Notes: Under the slope homogeneity hypothesis, the Hausman's statistic is asymptotically distributed as a Chi-squared variate. The table reports the value of the test statistic and the corresponding p-value in parenthesis.

Table 2: PSTR model for the growth rate of GDP per capita

\begin{tabular}{l|cccc}
\hline \hline \multirow{2}{*}{ Variable } & \multicolumn{3}{|c}{ Regime 1} & \multicolumn{3}{c}{ Regime 2} \\
Coef. & $t$-stat & Coef. & $t$-stat \\
\hline Misalignment & 0.052 & 2.00 & -0.038 & -3.46 \\
Inflation & -0.048 & -4.41 & 0.010 & 2.66 \\
Initial GDP per capita (log) & -0.033 & -5.58 & -0.031 & -1.35 \\
Investment (\% of GDP) & 0.033 & 2.55 & 0.064 & 2.10 \\
Openness (\% of GDP) & 0.022 & 3.38 & -0.021 & -0.12 \\
Pop. Growth & -0.699 & -2.11 & -0.983 & -0.59 \\
& & & & \\
Transition parameters & & & & \\
$\quad \hat{c}$ & 0.024 & & & \\
$\hat{\gamma}$ & 8.874 & & & \\
\hline \hline
\end{tabular}

Notes: (a) Regime 1 corresponds to $\Omega_{1}$ and $\theta_{1}$ in Equation (5); (b) Regime 2 corresponds to $\Omega_{1}+\Omega_{2}$ and $\theta_{1}+\theta_{2}$ in Equation (5); (c) $\hat{c}$ and $\hat{\gamma}$ are the estimated location and slope parameters, respectively, in Equation (4). 
Table 3: Linear growth equation (GMM estimation)

10

\begin{tabular}{l|cc}
\hline \hline Variable & Coeff. & $t$-stat \\
\hline Misalignment & -0.029 & -4.51 \\
Inflation & -0.027 & -11.93 \\
Initial GDP per capita $(\log )$ & -0.167 & -3.77 \\
Investment (\% of GDP) & 0.104 & 6.30 \\
Openness (\% of GDP) & 0.044 & 7.16 \\
Pop. Growth & -0.467 & -1.19 \\
& & \\
Specification test $(p$-value) & & \\
$\quad$ (1) Sargan test & 1.000 & \\
$\quad$ (2) Serial correlation & & \\
$\quad$ First order & 0.000 & \\
$\quad$ Second order & 0.260 & \\
\hline \hline
\end{tabular}

Notes: (a) Regressions are estimated using the dynamic GMM estimator; (b) Significant time dummies are included in the regressions; (c) Sargan test: test of the null hypothesis that the over-identifying restrictions are satisfied.

Table 4: Robustness checks. PSTR model for the growth rate of GDP per capita, with lagged values for trade openness and investment

\begin{tabular}{l|cccc}
\hline \hline \multirow{2}{*}{ Variable } & \multicolumn{3}{|c}{ Regime 1 } & \multicolumn{2}{c}{ Regime 2 } \\
& Coef. & $t$-stat & Coef. & $t$-stat \\
\hline Misalignment & 0.049 & 2.40 & -0.024 & -2.73 \\
Inflation & -0.047 & -5.64 & 0.010 & 2.98 \\
Initial GDP per capita (log) & -0.026 & -4.64 & -0.025 & -0.21 \\
Investment (\% of GDP) & -0.027 & -2.48 & 0.002 & 2.01 \\
Openness (\% of GDP) & 0.023 & 3.61 & 0.029 & 0.98 \\
Pop. Growth & $\mathrm{NS}$ & $\mathrm{NS}$ & $\mathrm{NS}$ & $\mathrm{NS}$ \\
& & & & \\
Transition parameters & & & & \\
$\quad \hat{c}$ & 0.109 & & & \\
$\hat{\gamma}$ & 10.514 & & & \\
\hline \hline
\end{tabular}

Notes: (a)-(c) idem notes Table 2; (d) NS: non significant. 
Table 5: Robustness checks. PSTR model for the growth rate of GDP per capita, HP filter and deviations from PPP equilibrium exchange rates

\begin{tabular}{|c|c|c|c|c|c|c|c|c|}
\hline & \multicolumn{4}{|c|}{$\overline{\mathrm{HP}}$} & \multicolumn{4}{|c|}{ PPP } \\
\hline & \multicolumn{2}{|c|}{ Regime 1} & \multicolumn{2}{|c|}{ Regime 2} & \multicolumn{2}{|c|}{ Regime 1} & \multicolumn{2}{|c|}{ Regime 2} \\
\hline & Coef. & $t$-stat & Coef. & $t$-stat & Coef. & $t$-stat & Coef. & $t$-stat \\
\hline Misalignment & 0.231 & 3.52 & -0.049 & -3.52 & 0.246 & 3.59 & -0.020 & -4.27 \\
\hline Inflation & -0.067 & -4.85 & 0.031 & 4.85 & -0.057 & -4.32 & 0.010 & 3.14 \\
\hline Initial GDP per capita (log) & -0.025 & -3.35 & -0.024 & -3.35 & -0.025 & -3.86 & -0.023 & -0.82 \\
\hline Investment ( $\%$ of GDP) & 0.011 & 0.72 & 0.115 & 0.71 & -0.015 & -0.61 & 0.122 & 3.13 \\
\hline Openness ( $\%$ of GDP) & 0.009 & 0.57 & 0.076 & 0.57 & 0.038 & 4.50 & 0.020 & 1.02 \\
\hline \multicolumn{9}{|l|}{ Transition parameters } \\
\hline$\hat{c}$ & 0.071 & & & & 0.002 & & & \\
\hline$\hat{\gamma}$ & 6.763 & & & & 3.326 & & & \\
\hline
\end{tabular}

Notes: (a)-(c) idem notes Table 2; (d) PPP is calculated as the difference between the actual log real exchange rate and the predicted one, the predicted value being obtained from a regression of the real exchange rate series on a constant plus a time trend.

\section{Appendix. Data definitions and sources}

The real effective exchange rate for each country $i$ is calculated as a weighted average of real bilateral exchange rates against each $j$ trade partner. Bilateral real exchange rates are derived from nominal rates and consumer price indices (CPI); they are based in $2000 .{ }^{15}$ The weights have been calculated as the share of each partner in average values of imports and exports of goods and services over the 2000-2007 period. ${ }^{16}$ Intra-Eurozone flows have been excluded and trade weights have been normalized to sum to one across the partners included in the sample.

The net foreign asset position is built using the Lane and Milesi-Ferretti database from 1980 to $2004 .^{17}$ To complete the database from 2005 to 2007 , we rely on the information provided by IFS (International Financial Statistics, IMF) and WDI (World Development Indicators, World Bank) on gross foreign assets and liabilities by applying the corresponding growth rates first on 2004 gross values, and then by reconstruction, to both sides of the international investment position for each country of the panel. Finally, the net foreign asset positions are

\footnotetext{
${ }^{15}$ Source: World Bank World Development Indicators (WDI) for nominal exchange rates and CPI data except for the EUR/USD exchange rate which was extracted from Datastream and China's real exchange rate which was calculated with GDP deflator (WDI).

${ }^{16}$ Source: IMF Direction of Trade Statistics (DOTS).

${ }^{17}$ Source: http://www.imf.org/external/pubs/cat/longres.cfm?sk=18942.0, see Lane and MilesiFerretti (2007).
} 
obtained by difference. ${ }^{18}$ We do the same for the Euro zone aggregate for which no data were available before 1999. To correct for intra-zone flows before 1999, we assumed that the share of external wealth accumulation due to intra-zone financial flows was the same than that due to intra-zone trade flows. By doing so, we obtain figures that can be easily linked to Lane and Milesi-Ferretti's estimations over the 1999-2004 period.

Turning to the other explanatory variables, the terms of trade are excerpted from WDI, except for the Euro zone and Chile (IFS). Concerning the proxy for relative productivity, we use the relative labor productivity of tradables to non tradables, measured by output per worker. It is calculated on the basis of a dataset for output and employment for a 6-sector classification (or 3 - sector when the 6-sector data were not available). ${ }^{19}$

The growth rate of real GDP per capita is extracted from the Penn World Table $6.1 .^{20}$ The explanatory variables are taken from IFS (inflation rate and government consumption), the Penn World Table 6.1 (real investment, trade openness-measured as the sum of exports and imports - and population growth), and the United Nations' database (gross-secondary school enrollment rate).

\footnotetext{
${ }^{18}$ Source: IMF (IFS), February 2009, and World Bank (WDI).

${ }^{19}$ We rely on the IMF classification (see IMF (2006)). The sources are the following: the United Nations Statistics Division, International Labor Office Bureau of Statistics, Eurostat, World Bank and Groningen Growth and Development Centre.

${ }^{20}$ Alan Heston, Robert Summers and Bettina Aten, Penn World Table Version 6.1, Center for International Comparisons at the University of Pennsylvania (CICUP), October 2002.
} 